\title{
Leadership Effect as a Moderating Variable to the Performance of CRM (UMN Case Study)
}

\author{
Arief Setyadi $\mathrm{H}^{1}$, Y Budi Susanto ${ }^{2}$, P. M. Winarno ${ }^{3}$ \\ \{ $\underline{\text { arief.setyadi@student.umn.ac.id }}$, $\underline{\text { bsusanto@umn.ac.id }}{ }^{2}$, pmwinarno@umn.ac.id $\left.^{3}\right\}$
}

MMT, Universitas Multimedia Nusantara, Indonesia ${ }^{1}$, MMT, Universitas Multimedia Nusantara, Indonesia $^{2}$, MMT, Universitas Multimedia Nusantara, Indonesia ${ }^{3}$

\begin{abstract}
By studying the influence of Leadership as a moderating variable in CRM implementation, can be concluded the Effect of Leadership as a Moderating Variable on Performance CRM providing successful implementation results. A study was conducted on CRM at UMN with a population and a sample of CRM users at UMN. The results showed that: Data and Information variables had a positive influence on the CRM performance variables at UMN, with R2 of 0.532; Process variables have a positive influence with R2 of 0.555; Technology variables have a positive influence with R2 of 0.498; The Human Resources variable has a positive influence with R2 of 0.570. Meanwhile, the Leadership variable as a Moderator Variable has increased the R Square for each variable.The results is the variable that has the most decisive influence on CRM performance is the Variable of Human Resources; for this, it needs special attention when implementing CRM.
\end{abstract}

Keywords: CRM, Leadership, Data and Information, Process, Technology, Human Resources

\section{Introduction}

\subsection{Success of CRM}

Consideration of the implementation of CRM is supported by the successful performance of CRM that has implemented by the following large companies: Tesco, Uber, Apple, Unilever, Amazon

\subsection{CRM Failure}

Not a few companies that implement CRM but have failed. Since Gartner's (2001) [3] study found a failure rate of CRM performance of 50\%, study after study reports a failure rate of between $30 \%$ and $70 \%$. More than a decade and a half of research on Customer Relationship Management (CRM) systems have resulted in consistently disruptive failure rates for CRM implementation. Farhan, Marwa Salah, et al. (2018) [12] provided the same data, almost about $70 \%$ of all CRM implementation projects failed to produce performance or achieve expected goals. Therefore, most researchers and information system developers concentrate on the approach to critical success factors that can increase CRM implementation's success and change the failures and weaknesses faced by CRM into the successful implementation and implementation of CRM systems.

\subsection{The Problem}

The problem formulation for this research is: How is Leadership's effect as a Moderating Variable to CRM Performance?

Then from the CRM failure research (not having good performance) as mentioned above, some factors influence the success or failure of this CRM performance. The author's assumption, there is one variable that becomes a moderator that can be a determining factor for this CRM can give a good or not performance. This determinant can be determined by evaluating the factors that influence the performance of CRM. 


\section{Literature Review}

Factors that can Influence CRM Performance

According to Judith W. Kincaid [8], an element that is also very important in CRM implementation is Data and Information; this is because, in the future, CRM operations always use data and information from both parties, namely the company or the customer. Thus, data and information need to be included in the factors that influence CRM performance by Judith. W. Kincaid [8], so that the development of factors that influence CRM performance is as below:

The factors that influence CRM performance used by Luke [10] and Judith W. Kincaid [8] to measure CRM performance have in common, and for the results of research by Judith W. Kincaid, added Data and Information factors. So the factors that can be used as variables in CRM performance measurement are like this:

$>$ Data and Information

$>$ Process

$>$ Technology

$>$ Human Resources

Leadership as a moderator variable

Verah Chianda and Yasir Mahmood (2013) [11] find exciting findings to understand CRM itself by people who hold Leadership at CRM adoption projects. At least in the case investigated by the authors, it affects almost every phase of CRM before adoption, adoption, implementation, and post-implementation phase.

Further published in the article titled "Kepemimpinan Bisa Pengaruhi Kualitas Sistem CRM Perusahaan" by Bisnis.com, Aina Neva Fiati (2017) [18] said: "The intended leadership includes culture and commitment to focus on customer service." Aina Neva Fiati is the Managing Director of iSystem Asia under another name PT Inter Sistem Asia.

Another critical factor, said Aina, is technology, social skills, and customer data processing. Of course, a technology that adds value and can adapt to the changing trends is so fast.

With this, the authors hypothesize that Leadership is a moderating variable that can be a determining factor in the implementation of CRM can provide good performance. These determinants can be determined by evaluating together with the factors that influence the performance of CRM.

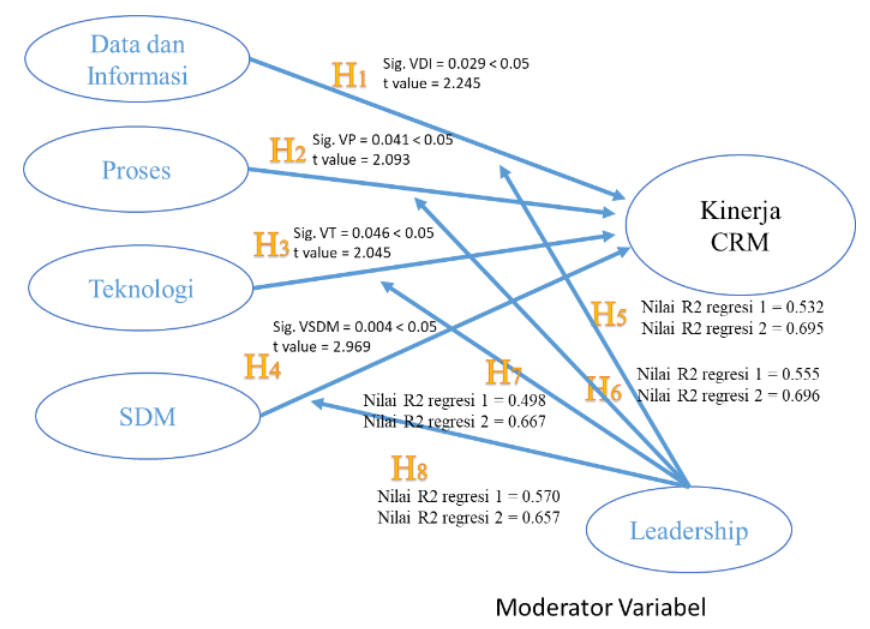

Fig 1. CRM Performance Measurement Model with Variables

\section{Hypothesis}

Based on the explanation of the factors that can influence CRM performance as explained above and additional author hypotheses regarding one moderator variable, namely Leadership, a framework model is created as above.

For each of the hypotheses, it can be explained as follows: 
Relationship of Data and Information with CRM Performance

- Based on Kincaid's (2004) theory, complete data and information about customers is the primary condition determining the company's success of CRM performance.

- Data for complete customer identification such as telephone numbers and e-mail addresses and other addresses that have been digitally stored in CRM significantly affect CRM performance

H1: Data and Information have a positive effect on CRM performance

H2: Process has Positive influential on CRM Performance

H3: Technology has a positive effect on CRM performance

H4: HR has a positive effect on CRM performance

H5: Leadership strengthens the influence of Data and Information on CRM Performance

H6: Leadership strengthens the effect of the Process on CRM Performance

H7: Leadership strengthens the influence of Technology on CRM Performance

H8: Leadership strengthens the influence of Human Resources on CRM Performance

\section{Methodology and Data Analysis Classic Assumption Test}

Steps that need to be taken or requirements that must be met before multiple-regression analysis are carried out to test the hypothesis to be examined must meet the requirements in the regression model. The steps or conditions that must be tested are: (the goal, ensuring that the regression made produces a model that is BLUES: Best Linear Unlock Estimator)

1. Normality Test is a testing model must have a normal distribution

2. Linearity Test is the existence of a linear relationship between the independent variable and the dependent variable partially

3. Multicollinearity test, there is no multicollinearity in the tested model

3. The heteroscedasticity test is to know that there is no symptom of heteroscedasticity in the model being tested

\section{Research Result and Discussion}

\section{Normality test}

With the data seen in the output table of the SPSS results, it is known that the value of the significant measure of AsyimpSig (2-tailed), which is 0.200 is more than the 0.05 standard. So, according to the basis of making decisions in testing the normality of Kolmogorovsmirnov above, the conclusion that can be drawn is the data have a normal distribution. This matter has fulfilled the assumption or normality requirements needed to do the regression model test.

\section{Linearity Test}

A linear relationship is signed between the Data and Information variables with the CRM Performance variable.

\section{Multikolinearitas Test}

With regard to the values of Tolerance and VIF, for Tolerance VDI $=0.299, \mathrm{VP}=0.317, \mathrm{VT}=0.335, \mathrm{VSDM}=0.487$, all Tolerance values exceed the magnitude of the specified standard value of 0.10 .

For VIF values of VDI $=3,349, \mathrm{VP}=3,154, \mathrm{VT}=2,986, \mathrm{VSDM}=2,052$, all VIF values $<$ from 10.00

Based on the conditions for decision making in the multicollinearity test, it can be concluded that there are no multicollinearity symptoms in the regression model under study.

\section{Heteroscedasticity Test}

Based on the above output results, it can be seen that the significance value (Sig.) For VDI $=0.861, \mathrm{VP}=0.757$, VT $=0.692$, and VSDM $=0.920$. Because all the significance values of the 4 Variables referred to exceed the magnitude of the standard number 0.05 , then based on decision-making conditions in conducting the glacial test, it can be concluded that there are no symptoms of heterosecdasticity in the regression model under study.

\section{Moderating Variable Analysis \\ MODERATING ANALYSIS}


Moderating variables are independent variables that make a stronger or weaker relationship between one independent variable with another to the dependent variable.

The value of R2 in the first regression is 0.532 , then in the second regression, the value of R2 increases to be 0.695. So with these results, it can be concluded that the influence of the Leadership Variable will make a stronger relationship between VDI with Var Performance CRM. (H5 received)

So with are all other Variable

\section{Multiple Linear Regression Test (Multiple Linear Regression)}

The typical steps for conducting a linear regression analysis are:

1. Determination coefficient test

2. F test as well

3. T-test

\section{Determination Coefficient Test}

By looking at the output in the SPSS table "Model Summary" above, it is known that the coefficient of Determination or RSquare value is 0.904 . RSquare value is obtained from doing the square of the correlation coefficient number or "R," which is $0.951 \times 0.951=0.904$. The amount of RSquare is worth 0.904 or equal to $90.4 \%$. This resulting figure means that VDI, VP, VT, and VSDM simultaneously positively influence the CRM Performance Variable of $90.4 \%$. While the figures outside that $(100 \%-90.4 \%=9.6 \%)$ are influenced by other variables outside of this regression equation research, and no specific research is conducted.

\section{Test $\mathbf{F}$}

By looking at the Significance numbers' value from the results of the ANOVA table, then according to the basic requirements for making decisions in the F test, if the Significance value of Sig. $<0.05$, which according to the table above, is Sig. $=0,000$, then VDI, VP, VT, and VSDM simultaneously positively influence CRM Performance Variables.

Tabel 1. Test $t$ result

\begin{tabular}{|c|c|c|c|}
\hline Coeffisients a \\
\hline Independent Variabel & $\begin{array}{c}\text { Standardized } \\
\text { Coefficients Beta }\end{array}$ & $\mathrm{t}$ & Sig. \\
\hline VDI & 0.247 & 2.245 & 0.029 \\
\hline VP & 0.240 & 2.093 & 0.041 \\
\hline VT & 0.245 & 2.045 & 0.046 \\
\hline VSDM & 0.268 & 2.969 & 0.004 \\
\hline
\end{tabular}

Dependent Variabel : CRM Performance

Based on the significant value of the SPSS output above, the Sig. from each variable:

Sig. VDI $=0.029<0.05$, Coeff Beta $=0.247$, then there is the effect of VDI on CRM Performance Var, it can be concluded Hypothesis (H1) is accepted

Sig. VP $=0.041<0.05$, Coeff Beta $=0.240$, then there is the effect of VP on the Var Performance of CRM, it can be concluded Hypothesis $(\mathrm{H} 2)$ is accepted

Sig. VT $=0.046<0.05$, Coeff Beta $=0.245$, then there is the effect of VT on the Var Performance CRM, it can be concluded Hypothesis (H3) is accepted

Sig. VSDM $=0.004<0.05$, Coeff Beta $=0.268$, then there is an effect of VSDM on the CRM Performance Var, it can be concluded that Hypothesis (H4) is accepted 


\section{Conclusion}

From the research results and test results, it was found that it was indeed found that evaluating CRM performance required factors that influenced it, namely VDI, VP, VT, and VSDM, as well as being strengthened by VL.

In practice, making CRM have an excellent performance needs to be explicitly processed and has a sure way to get as complete as possible from Customer Data and Information.

For CRM to provide optimal performance, it requires actors who at least understand the concept of CRM, understand the functions that exist in CRM, and the concept of objectives applied by CRM. Can not just any employee or person who suddenly entrusted with the chili task and then to immediately implement CRM. Knowledge, habits, and understanding are needed that require time and guidance.

By increasing the factors that affect CRM performance, namely VDI, VP, VT, and VSDM, and strengthened again by increasing VL, CRM's performance can be improved, CRM can be more useful to support the company's business processes.

\section{Implications / Limitations and Suggestions For Further Research}

To strengthen the influence of VDI, VP, VT, and VSDM, Leadership is needed on CRM performance. It is advisable and indeed necessary for a PIC who understands the concept of CRM and the concept of company business processes to then implement it in CRM and use CRM correctly and on time. Furthermore, what is no less critical is Leadership to use CRM continuously.

Suggestions for further research: research the use of CRM from the perspective of external companies or customers and other parties who interact through CRM.

\section{References}

[1] Chadwick, J. (2008). No 主観的健康感を中心とした在宅高齢者における 健康関連指標に関する共分散構

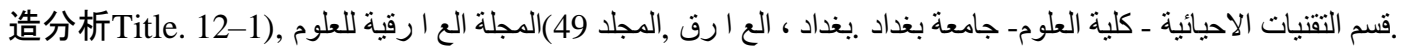

[2] D. A. F. Al-zoubi, "The Role of Customer Relationships Management in Achieving Competitive Advantage (A prospective study on a sample of employees at banks in Irbid city)," J. Mark. Manag., vol. 4, no. 1, pp. 137150, 2016, doi: 10.15640/jmm.v3n2a13.

[3]Gartner, Gartner. "Seven Key Reasons Why CRM Fails." Gartner, 1 Aug. 2001, www.gartner.com/en/documents/338949/seven-key-reasons-why-crm-fails.

[4]Ghalenooie, M. B., \& Sarvestani, H. K. (2016). Evaluating Human Factors in Customer Relationship Management Case Study: Private Banks of Shiraz City. Procedia Economics and Finance, 36(16), 363-373. https://doi.org/10.1016/s2212-5671(16)30048-x

[5] Ghozali, Imam. 2016. Aplikasi Analisis Multivariete Dengan Program IBM SPSS 23 (Edisi 8). Cetakan ke VIII. Semarang : Badan Penerbit Universitas Diponegoro.

[6] Hair JF, Black WC, Babin BJ, Anderson RE, and Tatham RL, 2006. Multivariate data analysis (6th ed.). Upper Saddle River, New Jersey: Pearson Education, Inc

[7] J. Kim, E. Suh, and H. Hwang, "A model for evaluating the effectiveness of crm using the balanced scorecard," J. Interact. Mark., vol. 17, no. 2, pp. 5-19, 2003, doi: 10.1002/dir.10051.

[8] Kincaid, Judith W. Customer Relationship Management: Getting It Right!. Google Books, Prentice Hall Professional, 2003

[9] Kotler, Philip \& Kevin Keller. Framework for Marketing Management \& Custom Case. 3rd Edition. New Jersey: Prentice-Hall, 2006.

[10]Lukas, Ade Paul. Customer and Partner Relationship Management. Jakarta: Telematic Research Group, 2001.

[11] Mahmood, Y., \& Chianda, C. The Importance Of leadership Role in CRM success as a Strategy, 2013.

[12] M. S. Farhan, A. H. Abed, and M. A. Ellatif, "A systematic review for the determination and classification of the CRM critical success factors supporting with their metrics," Futur. Comput. Informatics J., vol. 3, no. 2, pp. 398-416, 2018, doi: 10.1016/j.fcij.2018.11.003.

[13] S. H. Kale, "CRM failure and the seven deadly sins," Mark. Manag., vol. 13, no. 5, p. 42, 2004.

[14] Sekaran, U., \& Bougie, R. Research methods for business: A skill-building approach, 2016.

[15] Sugiyono. Metode Penelitian Kuantitatif, Kualitatif, dan R\&D. Bandung : Alfabeta, CV, 2017. 
[16]Y. B. Susanto, "The Impact of Market Orientation and Dynamic Marketing Capability on the Marketing Performance of ‘Make-To-Order' SMEs,” GATR J. Manag. Mark. Rev., vol. 4, no. 3, pp. 157-170, 2019, doi: 10.35609/jmmr.2019.4.3(1).

[17]Y. B. Susanto, S. C. Pratiwi, U. Multimedia, and S. Quality, "The Effect of Technology Readiness, Service Quality and Perceived Risk on Relationship Quality , and the Implications for Continuance of Intention - Study on Users of BCA Mobile Banking Applications," vol. 5, no. 6, pp. 720-734, 2019. [19]

[18] "Kepemimpinan Bisa Pengaruhi Kualitas Sistem CRM Perusahaan | Banten Bisnis.Com." Bisnis.Com, banten.bisnis.com/read/20171108/238/707177/kepemimpinan-bisa-pengaruhi-kualitas-sistem-crm-perusahaan. Accessed 4 Apr. 2020.

[19] "Why CRM Projects Fail and How to Make Them More Successful." Harvard Business Review, 14 Jan. hbr.org/2018/12/why-crm-projects-fail-and-how-to-make-them-more-successful, 2019.

[20] "25 Reasons Why Your CRM Fails...and How to Fix Them." Telestream, 30 Nov. 2017, www.intelestream.net/en/25-reasons-crm-fails-and-how-to-fix-them/, 2017. 